\title{
Venture Capital Financing and the Informativeness of Earnings*
}

\author{
Daniel A. Cohen ${ }^{\wedge}$ \\ Stern School of Business \\ New York University \\ Nisan S. Langberg \\ C.T. Bauer College of Business \\ University of Houston
}

\section{December 2006}

\begin{abstract}
Are there long-term costs to obtaining venture capital financing? We explore the hypothesis that venture capital backed firms do not efficiently transform to the corporate structure of public firms and have difficulties publicly communicating with arm's length investors. Our results are three fold. First, we find that, on average, reported accounting earnings are less informative for venture capital backed firms. Second, the informativeness of reported earnings is a decreasing function of venture capitalists' ownership of firm equity and a decreasing function of venture capitalists' board representation. Third, stock prices of venture capital backed firms reflect future earnings to a lesser extent relative to non-venture capital backed firms. Our findings support the hypothesis that venture capitalists manage the flow of public information to capital markets and preserve short term interests arising from specific investment and ownership horizons. This evidence suggests that the benefits of receiving venture capital financing are not without costs.
\end{abstract}

JEL Classification: M41, G14, G32

Keywords: Venture capital, earnings informativeness, ownership structure, investment horizon.

^Corresponding author, dcohen@stren.nyu.edu, (212) 998-0267

We thank Alicia Lofler, director of the Center for Biotechnology Research at the Kellogg School of Management, Northwestern University for institutional information and participants at the 2006 AAA Annual meeting in Washington DC, especially Myungsun (Sun) Kim (the discussant). 


\title{
Venture Capital Financing and the Informativeness of Earnings*
}

\begin{abstract}
Are there long-term costs to obtaining venture capital financing? We explore the hypothesis that venture capital backed firms do not efficiently transform to the corporate structure of public firms and have difficulties publicly communicating with arm's length investors. Our results are three fold. First, we find that, on average, reported accounting earnings are less informative for venture capital backed firms. Second, the informativeness of reported earnings is a decreasing function of venture capitalists' ownership of firm equity and a decreasing function of venture capitalists' board representation. Third, stock prices of venture capital backed firms reflect future earnings to a lesser extent relative to non-venture capital backed firms. Our findings support the hypothesis that venture capitalists manage the flow of public information to capital markets and preserve short term interests arising from specific investment and ownership horizons. This evidence suggests that the benefits of receiving venture capital financing are not without costs.
\end{abstract}

JEL Classification: M41, G14, G32

Keywords: Venture capital financing, earnings informativeness, ownership structure, investment horizon. 


\section{Introduction}

Efficient allocation of capital to high-growth startup companies is recognized as one of the most important challenges confronting capital markets as asymmetric information between founders and investors often lead to market failure. By unifying ownership and control, venture capitalists open the flow of funds between arm's length investors (e.g. pension funds, insurance companies, and other corporations) and entrepreneurs. The greatest impact of venture capital financing on economies around the world is undoubtedly manifested in the data on Initial Public Offerings (IPOs). Public firms, in contrast to private firms, operate under a completely different corporate structure.

In this paper we examine whether venture-capital backing affects the quality of financial reporting in the post-IPO period. In particular, we seek to investigate whether new public firms efficiently make the transition from being a private company to a public one. In addition, we are interested in analyzing whether there are any long term economic consequences associated with the choice of obtaining venture capital financing.

We address these issues by exploring newly public firms' ability to credibly communicate public financial information to diffused arm's length investors. Our main hypothesis, predicts that the degrees of control and ownership by venture capitalists affect public firms' financial information credibility and thus its quality as manifested in.....informativeness. Most research to date has focused and documented the benefits associated with receiving venture capital financing. However, to the extent that information asymmetries exacerbate agency problems, we interpret our results as suggesting that these benefits are not without costs. 
Throughout the paper, we deploy two methods, widely used in the accounting literature, to measure the informativeness of earnings. First, we focus on the slope coefficients relating annual stock returns to levels of earnings and changes in the levels of reported earnings. In addition, we also examine investors' reaction to quarterly earnings announcements. Viewing the informativeness of earnings as a measure for the market participants' confidence in the accounting information is not new (e.g. Teoh and Wong [1993]). ${ }^{1}$ Second, we investigate the extent to which stock prices reflect the relative dependence on current and future earnings, and adopt the approach discussed in Kothari and Sloan [1992]. The underlying premise is that when firms can credibly communicate with investors (in any form, be it public financial reports or not) then stock prices reflect future earnings to a greater extent. Consistent with our prediction, we find the opposite for venture capital backed firms. Our findings throughout the study are robust to controlling for the endogenous choice of venture capital.

We examine venture capitalists' incentives to manage the flow of public information to capital market participants. Specifically, in the model presented in the next section, reported earnings can be manipulated by insiders (e.g. venture capitalists) and thus may not represent the true underlying economic fundamentals of the firm (Lacker and Weinberg [1989]). In equilibrium, venture capitalists' incentives to manipulate earnings are determined by the equity prices that follow earnings announcements. Anticipating this behavior, uninformed investors value firm equity while taking into account the (endogenous) informativeness of earnings (Holthausen and Verrecchia [1988]). Our model predicts the informativeness of earnings to (i) be higher

\footnotetext{
1 Teoh and Wong [1993] analysis shows a positive relation between the credibility of accounting information and informativeness, interpreted as the coefficient estimate which relates stock returns to reported earnings.
} 
for non-venture backed firms relative to venture capital backed firms, (ii) be higher when the equity ownership of the venture capital firm is lower, and (iii) be higher when the board representation of the venture capital is lower.

Two main forces drive the theoretical results. First, venture capitalists play an active role in the development of the firms they finance. In the process, as a consequence, probably more than other investor, venture capitalists acquire private information regarding the firm's products, the potential product markets, the expected profits, among other things. For instance, venture capitalists often offer valuable consulting services (Gompers and Lerner [1999], Sahlman [1990]), have board representation and substantial control rights (Kaplan and Stomberg [2002]), shape and at times replace the management team (Hellman and Puri [2002]), and thoroughly screen and monitor the firms in the pre-funding stage.

Second, like pension funds, insurance companies, corporations and other institutional investors, venture capitalists own a substantial fraction of firm equity (Barry, Muscarella, and Vetsuypens [1990]). However, venture capital funds are unique in that they are (by law) limited in life span, and exist only for a period of ten to twelve years (Gompers and Lerner [1999], Sahlman [1990]). Therefore, among the equity holders and other decision makers in the newly public firm, venture capitalists may be more interested in advancing short-term performance at the expense of long-term growth. ${ }^{2}$ It is this specific conflict of interests arising from the limited investment and ownership horizon facing venture capital investors that we view as the potential cost associated with obtaining venture capital financing, as they might lead to inefficient decisions and reduce

\footnotetext{
${ }^{2}$ The compensation of venture capitalists typically depends on the fund's proceeds upon liquidation, i.e. the short-term performance of their investments (Gompers and Lerner [1999]).
} 
the overall firm value. This is in particular true when venture capitalists benefit the most from a profitable exit (e.g. when they own a substantial fraction of firm equity) and when they can more easily affect firm decisions, for instance, when they have substantial voting power or board representation.

The evidence we document suggest that the reported earnings of venture backed firms are less informative than earnings of non-venture-backed firms. We report the results after controlling for other determinants of earnings informativeness, such as firm size, loss observations, the book-to-market ratio, and leverage. We find that investors react less to a unit of unexpected earnings for venture backed firms and that the reaction depends on the incentives of the venture capitalist to manipulate earnings. Consistent with the model's predictions, we find that more equity the venture capitalist owns and the more board seats held by the venture capitalist, the less informative earnings are.

Out study contributes to two streams of research. First, we contribute to the literature which examines the role of financial intermediaries and in particular venture capitalists in the firms they invest in. Prior research has documented the economic consequences of venture capital financing, for example, the underpricing of IPOs (Magginson and Weiss [1991], Lee and Wahal [2002]), product market behavior (Hellman and Puri [2000]), corporate governance (Hochberg [2004]), and long-term returns (Brav and Gompers [1997]). We add to this literature by documenting the adverse effects venture capitalists have on the firm's informational environment subsequent to its going public. ${ }^{3}$ Second, we extend prior research which examines

\footnotetext{
${ }^{3}$ In a recent study, Hand [2005] examines the value relevance of financial statement data and non-financial data in the pre-IPO venture capital market and post-IPO market. Hand [2005] finds that for a sample of 193 biotechnology companies, financial statements are value relevant in the pre-IPO market. While both Hand [2005] and our study seeks to better understand the structure and characteristics of the information
} 
factors affecting the credibility of reported accounting earnings, as captured by the coefficient relating stock returns to earnings. Examples of such studies include Teoh and Wong [1993], Imhoff and Lobo [1992], Warfield, Wild, and Wild [1995], Subramanyam and Wild [1996], Fan and Wong [2002], Gul and Wah [2002], and Francis et al. [2005]. In particular, we extend the findings of studies which focused on the relation between ownership structure and control and the informativeness of earnings (e.g. Warfield et al. [1995], Fan and Wong [2002], and Francis et al. [2005]). We show that the ownership structure of newly public firms, in particular the presence of a venture capitalist, is an important determinant of the informativeness of earnings.

The remainder of the paper is organized as follows. In section 2 a simple model, upon which our empirical analysis builds on, is presented. Section 3 describes the data and the methodology used to estimate the informativeness of earnings, while in section 4 we discuss our findings. In Section 5 we deploy a second methodology to address our research question. Section 6 discusses the robustness of our results when including ownership by other institutional investors. We conclude in section 7 .

\section{A simple Model}

Consider a public firm that exists for three periods, $\mathrm{t}=0,1,2$ and is endowed with a risky project. The project yields in period $t=2$, Revenues $\mathrm{R}$, where $\mathrm{R}=\mathrm{U}$ with probability $\mathrm{p}$ and $\mathrm{R}=\mathrm{D}$ otherwise $(\mathrm{U}>\mathrm{D})$. For simplicity, we assume that this project is

environment of newly public firms, the studies differ in their specific research questions and research design. In particular, while Hand is interested in the value relevance of financial information in the private equity market, we investigate how venture capitals manage the flow of public information, and thus affect the informativeness of earnings versus non-ventured backed firms. We further discuss these issues in section 4 . 
the only asset of the firm and that revenues are net of payments to any debt holders. A venture capitalist (VC) is endowed with equity share $\alpha \in(0,1)$ in the firm.

Three properties of venture capitalists are emphasized in this study. First, venture capitalists are not long-term investors and eventually unwind their equity positions prior to the pre-specified liquidation date of their fund. Second, venture capitalists are informed investors. And third, venture capitalists can manage the flow of public accounting information received by capital markets participants by creating opacity regarding firm prospects (as discussed and formalized below).

In the model, the venture capitalist (VC) is required to sell his ownership of firm equity at time $\mathrm{t}=2$, while having private information regarding the distribution of future cash flows. The VC's private information, at this point, is summarized by a signal (with perfect precision) regarding the state of the firm. In other words, the VC knows if revenues will be $\mathrm{U}$ or $\mathrm{D}$ next period. The $\mathrm{VC}$ can manipulate the public signal regarding the true state of the firm $s^{p}$, by costly creating "opacity" at level $o_{i} \in[0,1]$ in states of the world $\mathrm{i}=\mathrm{U}, \mathrm{D}$.

$$
\operatorname{Prob}\left(\mathrm{s}^{\mathrm{p}}=\mathrm{U} \mid \mathrm{R}=\mathrm{U}, \mathrm{o}\right)=\operatorname{Prob}\left(\mathrm{s}^{\mathrm{p}}=\mathrm{D} \mid \mathrm{R}=\mathrm{D}, \mathrm{o}\right)=1-\mathrm{o}
$$

Thus, if there is no opacity (in other words, full transparency), i.e. $\mathrm{o}=0$, then there is no private information and the public is fully informed. However, as we will show, this is not characterized as an equilibrium. Finally, let $\beta \mathrm{c}(\mathrm{o})$ denote the cost to the $\mathrm{VC}$ of creating the opacity level $\mathrm{o} \in[0,1]$, where $\mathrm{c}^{\prime}(0)=0, \mathrm{c}^{\prime}(\mathrm{o}) \geq 0, \mathrm{c}^{\prime \prime}(\mathrm{o})>0$, and $\lim _{o \rightarrow 1} C(o)=\infty$. The coefficient $\beta$ is strictly positive and represents the control of the 
VC. Specifically, when the VC has substantial control in the firm, the cost of manipulation is lower, i.e. $\beta$ is lower.

\subsection{Equilibrium}

Consider first the problem of the $\mathrm{VC}$ at period $\mathrm{t}=1$. The optimal level of opacity, o, maximizes the expected price of firm equity. Therefore, it will not be optimal for the $\mathrm{VC}$ to create opacity when a good signal is received, i.e. $\mathrm{R}=\mathrm{U}$. Denote by o* the level of opacity the $\mathrm{VC}$ chooses in equilibrium when a bad signal is received, i.e. $\mathrm{R}=\mathrm{D}$. The publicly observed equity prices are based on public information.

Thus, we can write the price of equity at time $t=1$ as a function of public information, $\mathrm{P}\left(\mathrm{s}^{\mathrm{p}}\right)$. Also, let $\mathrm{P}_{0}=\mathrm{pU}+(1-\mathrm{p}) \mathrm{D}$ denote the price of equity at the outset (time $\mathrm{t}=0$ ) when there is symmetric information.

The equilibrium level of opacity solves:

$$
\begin{gathered}
\underset{o \in(0,1)}{M A X} \alpha\left[P(U) \operatorname{Pr} o b\left(s^{p}=U \mid R=D, o\right)+P(D) \operatorname{Pr} o b\left(s^{p}=D \mid R=D, o\right)\right]-\beta c(o) \\
\Rightarrow \beta c^{\prime}\left(o^{*}\right)=\alpha(P(U)-P(D))
\end{gathered}
$$

The equilibrium equity prices are given by:

$$
\begin{aligned}
& P(U)=U \operatorname{Pr} o b\left(R=U \mid o^{*}, s^{p}=U\right)+D \operatorname{Pr} o b\left(R=D \mid o^{*}, s^{p}=U\right) \\
& =U\left(\frac{p}{p+(1-p) o}\right)+D\left(1-\frac{p}{p+(1-p) o}\right) \\
& P(D)=U \operatorname{Pr} o b\left(R=U \mid o^{*}, s^{p}=D\right)+D \operatorname{Pr} o b\left(R=D \mid o^{*}, s^{p}=D\right)=D
\end{aligned}
$$

The equilibrium is implicitly given by: 


$$
\beta c^{\prime}\left(o^{*}\right)=\alpha[U-D]\left(\frac{p}{p+(1-p) o^{*}}\right)
$$

We can now define the price reaction to good news, $\Delta \mathrm{U}$, as the change in the price of equity as a result of the release of a good signal:

$$
\Delta U=p\left(\frac{1}{p+(1-p) o^{*}}-1\right)(U-D)
$$

\section{Proposition 1:}

(a) Manipulation takes place in equilibrium at level $\mathrm{o}^{*}>0$ defined by the equilibrium in equation (3).

(b) The degree of manipulation increases in VC ownership and in VC control, i.e. $\frac{\partial o^{*}}{\partial \alpha}>0$ and $\frac{\partial o^{*}}{\partial \beta}<0$

(c) The price reaction $\Delta \mathrm{U}$ is decreasing in VC ownership, i.e. $\frac{\partial \Delta U}{\partial \alpha}<0$.

(d) The price reaction, $\Delta \mathrm{U}$ is decreasing in VC control, i.e. $\frac{\partial \Delta U}{\partial \beta}>0$.

Proof: Follows from the above.

\section{Empirical Analysis}

In this section we compare the informativeness of earnings between venture and non-venture-backed firms and within the groups of venture backed firms. We define informativeness of earnings as the slope coefficient relating stock returns to reported 
accounting earnings, obtained from regressions of annual stock returns on annual earnings, and from short window returns analysis of quarterly earnings announcements.

Our approach builds on Teoh and Wong's [1993] analysis which shows a positive relation between the credibility of reported accounting information and informativeness, measured as the coefficient relating stock returns to earnings. Based on Proposition 1, we test the following hypotheses:

H1: Reported earnings are equally informative for venture and non-venture-backed firms.

H2: The informativeness of reported earnings does not vary with the venture capitalist's ownership of firm equity.

H3: The informativeness of reported earnings does not vary with the venture capitalist's representation on the firm's board of directors.

In order to focus on the implications of venture capital financing for the informativeness of earnings, we address the endogeneity of ownership structure. The decision of a firm to receive venture capital funding and the decision of a venture capitalist to provide such financing are not exogenous. Firm specific characteristics and information attributes may determine which firms are eventually venture capital backed. Therefore, the apparent endogeneity makes the issues of estimating the impact of venture capital financing on earnings informativeness challenging. To address this problem, we use an instrumental variables approach, following other studies in the existing literature (e.g. Baker and Gompers [2003]). We use two instruments for venture capital financing. 
The first instrument is the state where the firm is located. This information is obtained from COMPUSTAT. The motivation for using this variable as an instrument for venture capital is the concentration of the venture capital industry in several states, such as, California, Massachusetts, Texas, and Washington. This exact instrument was used by Baker and Gompers [2003], among others, in their study examining CEO compensation and venture capital financing. The second instrumental variable we are using is a dummy variable equal to one if the firm was founded after the year 1979. The amendment to the Employee Retirement Income Security Act of 1979, allowing pension funds to invest in venture capital partnerships, had a significant impact on money flowing into venture capital funds (Gompers and Lerner [1999]). This suggests that the probability of a firm being venture capital backed increased subsequently to 1979 . We report the results using both ordinary least squares and instrumental variables regressions.

We estimate the earnings informativeness association for samples that combine both venture and non-venture backed firms, and include the following factors which have been shown by prior research both to differ between venture and non-venture-backed firms and to be related to earnings informativeness.

Market-to-Book Ratio: This ratio serves as a proxy for investment opportunities. Collins and Kothari [1989] find that the book-to-market ratio is negatively associated with earnings informativeness; we include this variable in our regressions to control for the effect of investments opportunities on earnings informativeness.

Leverage: Dhaliwal, Lee, and Fargher [1991] document that the coefficient relating earnings to stock returns is decreasing in financial leverage. Thus, we need to condition for leverage in our informativeness tests. 
Size: Consistent with prior research (e.g. Jiambalvo et al. [2002], among others) we control for size when testing the relation between stock returns and earnings. We expect that the coefficient estimate relating earnings to stock returns is increasing in the firm's size.

Loss: We include a dummy variable for loss observations since Hayn [1995] provides evidence that the coefficient estimates relating stock returns and earnings are smaller for loss observations.

Hi-Tech: To address any concerns associated with the unique features of the hightech industry and their implications for earnings informativeness, we identify firms in the high-tech industry by including a dummy variable.

\subsection{Test of Earnings Informativeness}

We start our analysis of the differential informativeness of earnings for venture and non-venture-backed firms by examining the slope coefficients from regressions of annual stock returns on annual earnings. Following Easton and Harris [1991], we report tests for the level and changes in earnings. We include control variables for the marketto-book ratio, size, leverage, and whether earnings are positive, since these variables have been shown to influence earnings informativeness. The main regression we estimate is given in equation (5):

$$
\begin{aligned}
& R_{i, t}=\alpha_{0}+\alpha_{1} E A R N_{i, t}+\alpha_{2} E A R N_{i, t}{ }^{*} V C_{i, t}+\alpha_{3} \Delta E A R N_{i, t}+\alpha_{4} \Delta E A R N_{i, t}{ }^{*} V C_{i, t} \\
& +\alpha_{5} \operatorname{EARN}_{i, t} * \operatorname{LOSS}_{i, t}+\alpha_{6}{ }^{*} \operatorname{EARN}_{i, t} * \mathrm{HTECH}_{i, t} \\
& +\alpha_{7} \operatorname{EARN}_{i, t} * \operatorname{SIZE}_{i, t}+\alpha_{8} \operatorname{EARN}_{i, t} * \operatorname{MB}_{i, t}+\alpha_{9} E_{A R N_{i, t}} * E E V_{i, t}+\eta_{i, t}
\end{aligned}
$$

Where:

$R_{i, t}=$ firm i's 12-month cumulative raw return for fiscal year t. The 12-month interval 
starts three months following the end of the fiscal year t- 1 and ends three months after the end of fiscal year $t^{4}$

$E A R N_{i, t}=$ firm i's annual earnings (before extraordinary items) for fiscal year $\mathrm{t}$, scaled by market value of equity at the end of fiscal year t -1 .

$\triangle E A R N_{i, t}=$ change in $E A R N_{i, t}$ between year $\mathrm{t}-1$ and year $\mathrm{t}$, scaled by market value of equity at the end of fiscal year $\mathrm{t}-1$.

$V C_{i, t}=$ venture capital backing dummy variable equal to one if the company is venture capital backed, zero otherwise.

$\operatorname{LOSS}_{i, t}=$ dummy variable equal to one if $\mathrm{EARN}_{\mathrm{i}, \mathrm{t}}<0$.

$\mathrm{HTECH}_{i, t}=$ dummy variable equal to one if SIC code belongs to 2833-2836, 8731-8734,

7371-7379, 3570-3577, 3600-3674, zero otherwise.

$S I Z E_{i, t}=$ the log of firm's i market value of equity in year $\mathrm{t}$.

$M B_{i, t}=$ Market-to-Book ratio, the ratio of firm i's market value of equity to their book

value of equity at the end of year.

$L E V_{i, t}=$ firm's leverage, defined as the ratio of firm i's long term debt to total book value of assets at the end of year $\mathrm{t}-1$.

Under the null hypothesis $\mathrm{H} 1, \alpha_{2}+\alpha_{4}=0$; less earnings informativeness implies $\alpha_{2}+\alpha_{4}<0$ and greater earnings informativeness implies $\alpha_{2}+\alpha_{4}>0$.

Our second test of $\mathrm{H} 1$ examines the market reaction of venture backed firms versus non-backed firms to the earnings news conveyed in quarterly earnings announcements. Using Compustat quarterly earnings announcement dates and CRSP beta-adjusted abnormal returns, we calculate the three-day cumulative abnormal return for all quarterly earnings announcements during 1975-2003 made by our sample firms. We use a seasonal random walk model to measure unexpected earnings. We test the

\footnotetext{
${ }^{4}$ We obtain similar results (not tabulated) if we cumulate stock returns over the 15 -month period starting at the end of year $t-1$.
} 
differential sensitivity of returns to unexpected earnings for venture capital backed firms and non-backed firms by estimating equation (6), where the null hypothesis predicts that $\lambda_{2}=0$ :

$C A R_{, q, t}=\lambda_{0}+\lambda_{1} U E_{i, q, t}+\lambda_{2} U E_{i, q, t} * V C+v_{i, q, t}$

Where:

$C A R_{i, q, t}=$ cumulative abnormal return over the three days $(-1,1)$ centered on firm i's announcement of quarter q earnings for year $t$.

$U E_{i, q, t}=$ unexpected earnings of quarter $\mathrm{q}$ earnings for year $\mathrm{t}$, measured as the difference between reported earnings for quarter $\mathrm{q}$ of year $\mathrm{t}$ and reported earnings for quarter q of year $\mathrm{t}-1$, scaled by the share price at the end of the prior fiscal quarter. ${ }^{5}$

\subsection{Conditional Tests of Earnings Informativeness}

In this section we test how venture capital ownership and the board of directors' characteristics affect the informativeness of earnings for a reduced sample of venture backed firms. We estimate the following two regressions:

$$
\begin{aligned}
& R_{i, t}=\alpha_{0}+\alpha_{1} E A R N_{i, t}+\alpha_{2} \Delta E A R N_{i, t}+\alpha_{3} E A R N_{i, t} * \operatorname{LOSS}_{i, t}+\alpha_{4}{ }^{*} E A R N_{i, t} * H T E C H_{i, t} \\
& +\alpha_{5} \operatorname{EARN}_{i, t} * \operatorname{SIZE}_{i, t}+\alpha_{6} E A R N_{i, t} * M B_{i, t}+\alpha_{7} E_{A R N_{i, t}} * L E V_{i, t}+ \\
& +\alpha_{8} E A R N_{i, t}{ }^{*} O W N_{i, t}+\alpha_{9} \Delta E A R N_{i, t}{ }^{*} O W N_{i, t}+\alpha_{10} E A R N_{i, t}{ }^{*} S E A T_{i, t} \\
& +\alpha_{11} * \Delta E A R N_{i, t} * S E A T_{i, t}+\eta_{i, t} \\
& C A R_{i, q, t}=\lambda_{0}+\lambda_{1} U E_{i, q, t}+\lambda_{2} U E_{i, q, t} * O W N_{i, t}+\lambda_{3} U E_{i, q, t} * S E A T_{i, t}+v_{i, t}
\end{aligned}
$$

Where

\footnotetext{
${ }^{5} \mathrm{We}$ also scaled by the market value of equity 30 days prior to the earnings announcements, for observations where share price was available on this particular date. The results (untabulated) are not sensitive to this alternative specification.
} 
$\mathrm{OWN}_{\mathrm{i}, \mathrm{t}}=$ percentage of equity owned by venture capital firms at date of IPO.

$\mathrm{SEAT}_{\mathrm{i}, \mathrm{t}}=$ percentage of seats on board of directors occupied by venture capital firms

\subsection{Data and Sample}

The analysis is based on data obtained from the following data sources: the 2003 Compustat annual and quarterly industrial and research files, the 2003 CRSP files, and SDC for 1975-2003. Unit offerings and IPOs with an offer price of less than $\$ 5.00$ are not included in our sample. We eliminated IPOs for which we could not identify valid CUSIP numbers. These criteria results in a main sample which consists of 6,670 IPOs for which we have both financial data and stock return data. Data for the reduced venture backed sample we use in the second part of the analysis is based on the Barry et al. [1990] venture capital data for the period 1978-1987. The main sample consists of 2,202

venture backed IPOs versus 4,468 non-backed IPOs. We obtain the venture backing classification from SDC. For the reduced sample of venture backed IPOs, we have 423 firms with ownership and board of directors characteristics.

\subsection{Descriptive Statistics}

Table 1 documents the industry distribution of venture backed IPOs across 2-digit SIC codes. Across all industries, venture backed IPOs represent $34 \%$ of all IPOs. This figure is very close to the $37 \%$ venture backed sample used in a recent study by Lee and Wahal [2004]. There is a significant variation across industries, from a zero in the Petroleum industry (SIC code 28) to a high of 55\% in the Business Services (SIC code 73). In a finer analysis we find a large concentration of venture backed IPOs in SIC code 
7372 - software firms (15\%) and in the biotechnology industry (SIC code 8731, among others $-8 \%)$.

Table 2 reports the geographic distribution of venture backed IPOs. We find that the most venture backed IPOs are concentrated in California, Massachusetts, and Texas. These three states represent more than $50 \%$ of the overall venture backed IPOs. This concentration is not surprising given that prior research has documented that venture capital backed firms are located closer to areas where private equity markets are more developed. Usually, the interpretation for such a finding is that venture capital firms want to closely monitor their investments, thus increasing the concentration of venture backed firms in those specific geographical areas.

Table 3 reports specific firm characteristic of venture backed versus non backed firms. Venture backed firms have higher market values, smaller assets and lower book values, less sales revenues, and are less leveraged. In addition, venture backed firms are more likely to report negative earnings compared to non backed firms.

\section{Results}

The results of estimating equation (5) are reported in Table 4. Consistent with prior research, the annual regression relating stock returns to the level and change in earnings provides positive coefficient estimates (both significant at the 0.001 significance level). In line with the results documented in Collins and Kothari [1989], we find that the coefficient estimate for the interaction between earnings and the market-to-book ratio is positive. We also find that earnings informativeness is decreasing in leverage. This finding is consistent with firms having greater incentives to manage earnings in the 
presence of covenant restrictions associated with leverage which makes earnings quality, and thus earnings response coefficients lower for firms which are more leveraged. Finally, we find, as one would expect, that venture backed firms in the high-tech industries have less informative earnings, as suggested by the negative and significant coefficient $\hat{\alpha}_{6}$.

With respect to our main variables of interest, EARN*VC and $\triangle \mathrm{EARN} * \mathrm{VC}$, the estimates of $\hat{\alpha}_{2}$ and $\hat{\alpha}_{4}$ are -0.260 and -0.323 respectively. The sum of the two coefficient estimates is --0.583 , $\mathrm{p}$-value of 0.0001 . These results support our hypothesis that the earnings of venture backed firms are less credible and thus providing a lower level of informativeness. In terms of the magnitude of these effects, a one unit variation in the change in earnings is about half as informative for venture backed firms as it is for non-venture backed firms. Columns two and three in Table 4 report the results when we use an instrumental variable in lieu of the venture capital dummy. When we use as instruments the geographic location of the firm or the dummy for the year of founding, we find results which are consistent with the previous findings documented in column one of Table 4.

Our next test of Hypothesis H1 investigates the capital market's reaction to the earnings news conveyed in quarterly earnings announcements of venture backed firms and non-venture backed firms. The results estimating equation (6) are reported in Table 5. Consistent with prior research, we find a positive and significant value of unexpected earnings (UE). The coefficient estimate $\hat{\lambda}_{2}$, which is significantly negative suggests that investors respond less to a unit of unexpected earning for venture backed firms than for 
non backed venture firms $\left(-0.067\right.$, t-statistic -6.94). Comparing the estimates $\hat{\lambda}_{1}$ and $\hat{\lambda}_{2}$ suggests that quarterly earnings announcements are about half as informative for venture backed firms relative to non-venture backed firms. Repeating the analysis using the instrumental variables, rather than the venture capital dummy, provides the same results. Overall, these results suggest that venture capital backing decreases the valuation weigh investors place on reported earnings of such firms.

In Table 5, Panel B, we further explore the relation between venture capital ownership and the informativeness of earnings for the sub-sample of high-tech firms. In particular, we add the variable AGE to equation (6), which is defined as the logarithm of the number of months since the company became public. By doing so, we can explore the changes in the informativeness of earnings as the firms become more mature. For non-venture backed firms the informativeness of earnings is not affected by the variable AGE. However, the informativeness of earnings increases in the period following the IPO for venture backed firms. We view this as evidence of a gradual increase in informativeness due to the gradual decrease in venture capitalists' ownership of firm equity, in the period following the IPO. For the main sample, however, we did not find a significant difference in the effect of the firm's maturity on the informativeness of earnings.

The evidence in Table 5, Panel B, is consistent with the results reported in Hand [2005]. He finds that the value relevance of financial statements increases as the firm matures and suggests that this is due to the increasing intensity of assets in place relative to future investment options. Given his focus on a sample of biotechnology firms, Hand's evidence is similar to our finding, for the more general high-tech industry. 


\subsection{Venture Capital Ownership and Earnings Informativeness}

We test hypotheses $\mathrm{H} 2$ and $\mathrm{H} 3$ by focusing on the reduced sample of venture backed firms as in Barry et al. [1990]. Results are reported in Table 6, Panels A and B. The evidence in Table 6, Panel A suggests that while EARN and $\triangle E A R N$ are still positive and significant (as for our main sample), venture capital ownership decreases the informativeness of earnings. In addition, we find that the larger the influence and control of venture capital firms on the boards of directors, as evidenced in the percent of the seats they have on the board, the lower the informativeness of earnings. When we include both the ownership variable $(\mathrm{OWN})$ and the board influence variable (SEAT), we find that only the SEAT variable continues to significantly decrease the informativeness of earnings, after controlling for the ownership stake of the venture capitalist. Table 6, Panel B presents the results of testing how board characteristics and venture capital ownership affects the market's reaction to quarterly earnings announcements. In line with the results we report in Table 6, Panel A, we find that the higher the ownership stake of venture capital funds and the more influence these funds have on the board of directors, the less the market reacts to the earnings news signal as conveyed in the quarterly earnings announcement. As in Panel A, only the SEAT variable is significant once both variables - OWN and SEAT are interacted with UE (unexpected earnings).

Overall, the results in Table 6 suggest that as the ownership of venture capitalists increases, capital markets' investors decrease the valuation weight on earnings. While some of the control variables account for the variation in earnings informativeness, a significant portion is still unexplained by these variables. We conclude that the unexplained portion in earnings informativeness is attributed to investors perceptions that 
venture capitalists influence the public financial reporting process in such ways that reduces the credibility of earnings and thus its informativeness.

The empirical evidence to date is mixed regarding the association between ownership structure and earnings informativeness. On one hand, Warfield et al. [1995] find a positive relation between managerial ownership and earnings informativeness, whereas Fan and Wong [2002] find a negative relation between ownership and earnings informativeness for their sample of East Asian firms with concentrated ownership. ${ }^{6}$ Related to these studies, Francis et. al [2005] do not find evidence that management ownership affects earnings informativeness for their specific sample.

Taken as a whole, the results documented so far indicate that there is a long-term cost associated with being backed by venture capital financing. In particular, one implication of these results is that venture capital backed firms have information related problems which might affect their ability to raise capital in the future. The specific test of this assertion is left for future research.

\section{An Alternative Test of Communication Efficiency}

As in Jiambalvo et al. [2002] who examine the influence of institutional investors on the informativeness of earnings, we assess the extent to which stock prices lead accounting earnings conditional on venture capital backing. Specifically, we examine whether the stock prices of venture-capital backed firms impound more or less information about current earnings relative to future earnings. If venture capitalists are characterized as transient investors who are more concerned with current short term-

\footnotetext{
${ }^{6}$ In particular, Fan and Wong [2002] find that concentrated ownership, created by cross holdings and pyramid structures that separate cash flow rights from voting rights, decreases the informativeness of earnings.
} 
profitability they will lack any incentives to become informed regarding the future prospects of the firm they are invested in. Stated differently, venture capitalists will focus only on current earnings as a measure of profitability. If venture capitalists are over focusing and emphasize short-term profitability as reflected in current reported earnings instead of future profitability, we might expect that stock prices of venturebacked firms will reflect more information contained in current reported earnings relative to the information contained in future earnings. The main motivation for investigating these empirical predictions is due to the limited investment and ownership horizon faced by venture capitalists. As we stated earlier, venture capitalists are required by law to liquidate their equity holdings and exit the newly public firms they have invested in during a specific time frame.

In order to examine the extent to which stock prices reflect the relative dependence on current and future earnings, we adopt the approach discussed in Kothari and Sloan [1992]. It is well known that stock prices lead earnings since not all the economic actions undertaken by the firm are reflected in current earnings but such actions are available and known to investors. These economic actions, although known to investors and not reflected in current reported earnings will be reflected in future earnings. Under this scenario, if investors impound value-relevant information which is not reflected in current earnings, current stock prices will reflect the information regarding future earnings, after controlling for current earnings.

Kothari and Sloan [1992] use the premise that stock prices lead accounting earnings and suggest the following association:

$$
R_{i t, t-\tau}=\theta_{0}+\theta_{1(\tau)} \frac{E_{i t}}{P_{i t-\tau}}+v_{i t-\tau}
$$


Where:

$R_{i t, t-\tau}=$ The buy-and-hold return for firm i over the period $\mathrm{t}-\tau$ to $\mathrm{t}$.

$E_{i t} \quad=$ Income before extraordinary items for the accounting period ended at time $\mathrm{t}$.

$P_{i t-\tau}=$ The stock price at the end of period $\mathrm{t}-\tau$.

The capital market's response during the period $t-\tau$ to $t$ to accounting earnings information for the period ended at time $t$ is represented by $\theta_{1(\tau)}$.

The discussion in Kothari and Sloan [1992] suggests that as the interval $\tau$ increases, more information contained in reported earnings at time $t$ would be reflected in the return cumulated over the period t- $\tau$ to $t$. This is the case since the capital market's expectation about future profitability will be reflected earlier in stock prices but only later in reported accounting earnings. If the information contained in current reported earnings has been already reflected in stock prices in the previous period, the coefficient $\theta_{1(\tau)}$ will get smaller (larger) as the interval $\tau$ gets smaller (larger). This implies that $\theta_{1(\tau)}$ when $\tau=2$ is larger than for $\tau=1$. The ratio of $\theta_{1(\tau)}$ obtained for a longer time interval to the one obtained for a shorter interval (i.e., $\left.\frac{\theta_{1(\tau=2)}}{\theta_{1(\tau=1)}}\right)$ will provide a measure of the firm's information environment. The higher the ratio is, the more information in current reported earnings has already been reflected in previous stock returns.

If venture capitalists can be classified as transient investors who myopically focus on short term reported accounting earnings given their limited investment and ownership horizon, one would expect the ratio $\frac{\theta_{1(\tau=2)}}{\theta_{1(\tau=1)}}$ to be smaller for venture-backed firms than for non-backed firms. In other words, stock prices of venture backed firms would be more 
sensitive to current reported earnings relative to future earnings than stock prices of nonbacked firms. To investigate this prediction, we estimate the coefficient $\theta_{1(\tau)}$ separately for venture-backed firms and non-backed firms for $\tau=1$ and for $\tau=2$. Next, we calculate the ratio $\frac{\theta_{1(\tau=2)}}{\theta_{1(\tau=1)}}$ for each group and test whether ratio is lower for the venture-backed firms. A smaller ratio for venture-backed firms compared to the non-backed firms is consistent with the assertion that venture capital investors can be classified as transient investors with a short term investing horizon.

The results of estimating equation (9) for venture-backed versus non-backed firms and for the two time periods ( $\tau=1$ and $\tau=2$ ) are reported in Table 7. Panel A reports the results of a univariate estimation while the multivariate analysis after controlling for the interaction of reported earnings with other determinants of the earning-return relationship (SIZE, LEV, MB, LOSS) is reported in Panel B. Consistent with the findings in Kothari and Sloan [1992] the estimated coefficients $\theta_{1(\tau)}$ for both the venture-backed and nonventure backed firms increase with the time interval over which stock returns are computed. This finding is consistent with the claim that stock prices lead accounting earnings. Our main focus is on the ratio $\frac{\theta_{1(\tau=2)}}{\theta_{1(\tau=1)}}$ that captures the extent to which stock prices lead earnings across venture and non-venture backed firms. The results suggest that the ratio $\frac{\theta_{1(\tau=2)}}{\theta_{1(\tau=1)}}$ is significantly lower for the venture-backed firms (1.53 for venture backed firms versus 1.88 for non-backed firms, and 1.45 versus 1.82 once the control variables are included (Panel B)). This finding is consistent with the view that venture capital investors can be characterized as transient owners which are myopically focused 
on short-term earnings. This evidence runs contrary to the evidence documented in Jiambalvo et al. [2002] who found that institutional investors, as opposed to venture capital investors, are not fixated on current reported earnings.

\section{Is This Just an "Institutional Investor Effect?"}

Given prior research on the effect on institutional holdings on the informativeness of reported earnings, we have repeated the analysis of the earnings-returns relationship after controlling for institutional investors holdings. Even after controlling for institutional investors holdings, we continue to find evidence that the reported accounting earnings are less informative for venture-backed firms. This finding suggests that unlike institutional investors, venture capital owners decrease the quality of the information reported to capital markets participants by the firms they invest in and influence the decision making process.

\section{Concluding Remarks}

The extant literature by far has documented the benefits of venture capital financing. These benefits range from the valuable strategic advice, business plans and industry connections provided by venture capitalists to newly public firms, to the high quality of underwriters and the low under pricing of IPOs enjoyed by venture-backed firms. Our results suggest that these benefits do not come without costs.

Our findings suggest that venture capital backed firms have difficulties in credibly communicating with investors. We show that the informativeness of public accounting information for the pricing of firm equity indeed depends on the ownership structure of 
the firm. The results are robust to attempts to control for firms' decision to obtain venture capital in the first place. The results are also robust to looking at a sub-sample of more homogenous firms, those in high-tech industries. Finally, we adopt an alternative methodology to explore whether venture capital backed firms just use alternative channels of information to communicate with investors.

To further explore our hypothesis that venture capitalists manage the flow of information to capital market participants we investigate whether firms backed by venture capitalists that are more likely to benefit from higher equity prices or that can better control firm decisions have less informative earnings. The findings are consistent with this view. Overall, these results suggest that venture capitalists might be promoting short-term interest given their different investment horizon at the expense of long-term investors.

Taken as a whole the results we present indicate that there is a cost associated with being backed by a venture capitalist. Our theory suggests that the conflict of interest between long-term equity investors and venture capitalists who seek to promote shortterm performance leads to less informative earnings as one of its attributes. This by itself might affect the firm's ability to raise capital in the future and reduce firm value. However, the underlying conflict of interest we emphasize may bring about the inefficiency of other firm decisions. The specific test of this assertion is left for future research. 


\section{References}

Baker, M. and P. Gompers, 2003. The Determinants of Board Structure at the Initial Public Offering, Journal of Law and Economics, 46: 569-598.

Barry, C., C. Muscarella, and M. Vetsuypens, 1990, The Role of Venture Capital in the Creation of Public Companies, Journal of Financial Economics 27: 447-471.

Bushee, B. 1998. The Influence of Institutional on Myopic R $\ \& D$ Investment Behavior. The Accounting Review, Vol. 73: 305-333.

Brav, A. and Gompers, P. 1997. "Myth or Reality? The Long-Run Underperformance of Initial Public Offerings: Evidence from Venture and Nonventure Capital-backed Companies". Journal of Finance, Vol. 52 no. 5.

Collins, D. and S.P. Kothari. 1989. An analysis of intertemporal and cross-sectional determinants of earnings response coefficients. Journal of Accounting and Economics 11: 143-181.

Dhaliwal, D., K. Lee and N. Fargher. 1991. The association between unexpected earnings and abnormal security returns in the presence of financial leverage. Contemporary Accounting Research 8: 20-41.

Easton, P. and T. Harris. 1991. Earnings as an explanatory variable for returns. Journal of Accounting Research 29, 1: 19-36.

Easton, P. and M. Zmijewski. 1989. Cross-sectional variation in the stock market response to accounting earnings announcements. Journal of Accounting and Economics 11, 2/3: 117-141.

Fama, E. and J. MacBeth. 1973. Risk, return and equilibrium: Empirical tests. Journal of Political Economy 81: 607-636.

Fan, J. and T.J. Wong. 2002. Corporate ownership structure and the informativeness of accounting earnings in East Asia. Journal of Accounting and Economics 33: 401-425.

Francis, J., Katherine Schipper, and Linda Vincent. Earnings and Dividend Informativeness when Cash Flow Rights are Separated from Voting Rights, Journal of Accounting and Economics 39 (2), March 2005 forthcoming.

Freeman, R. 1987. The association between accounting earnings and security returns for large and small firms. Journal of Accounting and Economics 55: 615-646.

Gompers, P.A. and J. Lerner, 1999. The Venture Capital Cycle. Cambridge: MIT Press.

Gul, F., and L.K. Wah. 2002. Insider entrenchment, board leadership structure and informativeness of earnings. Working paper, City University of Hong Kong. 
Hayn, C. 1995. The information content of losses. Journal of Accounting and Economics 11: $123-153$.

Hellmann, T., and M. Puri, 2000, The Interaction between Product Market and Financing Strategy: The Role of Venture Capital, Review of Financial Studies 13, 959-984.

Hellmann, T., and M. Puri, 2002, Venture Capital and the Professionalization of Start-up Firms: Empirical Evidence, The Journal of Finance 57, 169-197.

Hochberg, Y. 2004. Venture Capital and Corporate Governance in the Newly Public Firm, working paper, Cornell University.

Holthausen, R. and R. Verrecchia. 1988. The effects of sequential information releases on the variance of price changes in an inter-temporal asst multi-asset market. Journal of Accounting Research 26: 82-106.

Imhoff, E. and G. Lobo. 1992. The effect of ex ante earnings uncertainty on earnings response coefficients. The Accounting Review 67: 427-439.

Jiambalvo, J., S. Rajgopal, and M. Venkatachalam. 2002. Institutional ownership and the extent to which stock prices reflect future earnings. Contemporary Accounting Research 19 (Spring): 117-145.

Kaplan, Steven and Per Stromberg, 2002. Characteristics, contracts and actions: Evidence from venture capital analyses, working paper, University of Chicago.

Kothari, S.P. and Richard G. Sloan. 1992. Information in Prices about Future Earnings: Implications for Earnings Response Coefficients. Journal of Accounting and Economics $15(2,3): 143-171$.

Lacker, Jeffrey M \& Weinberg, John A, 1989. "Optimal Contracts under Costly State Falsification," Journal of Political Economy, University of Chicago Press, vol. 97(6), pages 1345-63.

Lerner, J. 1995. Venture Capitalists and the Oversight of Public Firms. Journal of Finance 50, page 301-318

Lee, Peggy M. and Wahal, Sunil, 2002 "Grandstanding, Certification and the Underpricing of Venture Backed IPOs" working paper Emory University.

Megginson, W. and K. Weiss, 1991, Venture Capitalist Certification in Initial Public Offerings, Journal of Finance 46: 879-903.

Sahlman, William A. 1990. The Structure and Governance of Venture Capital Organizations, Journal of Financial Economics 27: 473-521.. 
Subramanyam, K.R., and J. Wild. 1996. Going-concern status, earnings persistence, and informativeness of earnings. Contemporary Accounting Research (Spring): 251-273.

Teoh, S., and T.J. Wong, 1993. Perceived auditor quality and the earnings response coefficient. The Accounting Review 68: 346-366.

Warfield, T., J. Wild and K. Wild. 1995. Managerial ownership, accounting choices and informativeness of earnings. Journal of Accounting and Economics 20: 61-91.

Yeo, G., P. Tan, K. Ho and S. Chen. 2002. Corporate ownership structure and the informativeness of earnings. Journal of Business, Finance and Accounting 29: 10231046. 
Table 1: Descriptive Statistics on Industry Composition and Venture Capital Backing for the Sample Period, 1975 - 2003

\begin{tabular}{|c|c|c|}
\hline 2 Digit SIC & Industry & $\begin{array}{l}\text { Percent of Venture } \\
\text { Backed Firms }\end{array}$ \\
\hline 1 & Crops & 0.175 \\
\hline 10 & Ores & 0.000 \\
\hline 13 & Oil and Gas & 0.189 \\
\hline 14 & Quarry & 0.000 \\
\hline 15 & Building - Light & 0.062 \\
\hline 16 & Building - Heavy & 0.035 \\
\hline 17 & Construction & 0.200 \\
\hline 20 & Food & 0.178 \\
\hline 22 & Textile Mill & 0.244 \\
\hline 23 & Apparel & 0.147 \\
\hline 24 & Lumber & 0.019 \\
\hline 25 & Furniture & 0.251 \\
\hline 26 & Paper & 0.306 \\
\hline 27 & Printing & 0.326 \\
\hline 28 & Chemicals & 0.319 \\
\hline 29 & Petroleum & 0.000 \\
\hline 30 & Rubber & 0.189 \\
\hline 31 & Leather & 0.000 \\
\hline 32 & Stone & 0.161 \\
\hline 33 & Metal Work - Basic & 0.129 \\
\hline
\end{tabular}


Table 1 (Continued)

\begin{tabular}{lll}
\hline 2 Digit SIC & Industry & $\begin{array}{l}\text { Percent of Venture } \\
\text { Backed Firms }\end{array}$ \\
\hline 34 & Metal Work Fabrication & 0.264 \\
35 & Industrial & 0.556 \\
36 & Electrical & 0.499 \\
37 & Transport - Equipment & 0.154 \\
38 & Instruments & 0.562 \\
39 & Misc. Manufacturing & 0.209 \\
40 & Railroad & 0.178 \\
42 & Motor Freight & 0.327 \\
44 & Water Transport & 0.118 \\
45 & Air Transport & 0.072 \\
47 & Transport - Services & 0.102 \\
48 & Communications & 0.349 \\
49 & Utilities & 0.240 \\
50 & Durables - Wholesale & 0.291 \\
51 & NonDurables & 0.141 \\
52 & Wholesale & 0.293 \\
53 & Garden & 0.223 \\
54 & General Stores & 0.092 \\
55 & Food Stores & 0.176 \\
56 & Auto Dealers & 0.211 \\
\hline & Apparel - Retail & \\
\hline
\end{tabular}




\section{Table 1 (Continued)}

\begin{tabular}{|c|c|c|}
\hline 2 Digit SIC & Industry & $\begin{array}{l}\text { Percent of Venture } \\
\text { Backed Firms }\end{array}$ \\
\hline 57 & Home Equipment & 0.281 \\
\hline 58 & Eating & 0.232 \\
\hline 59 & Misc. Retail & 0.231 \\
\hline 60 & Commercial Bank & 0.025 \\
\hline 63 & Hospital and Medical & 0.219 \\
\hline 64 & Insurance & 0.102 \\
\hline 65 & $\begin{array}{l}\text { Operators Non- } \\
\text { Residence Buildings }\end{array}$ & 0.131 \\
\hline 67 & Real Estate & 0.178 \\
\hline 70 & Hotels & 0.000 \\
\hline 72 & Personal Services & 0.127 \\
\hline 73 & Business Services & 0.561 \\
\hline 75 & Auto Repair & 0.493 \\
\hline 78 & Movies & 0.126 \\
\hline 79 & Amusements & 0.157 \\
\hline 80 & Health & 0.485 \\
\hline 81 & Legal Services & 0.000 \\
\hline 82 & Educational & 0.098 \\
\hline 83 & Social & 0.308 \\
\hline 87 & Engineering - Retail & 0.363 \\
\hline
\end{tabular}


Table 2: Geographic Distribution of Venture Backed IPOs, for the Sample Period, $1975-2003$

\begin{tabular}{lcc}
\hline State & $\begin{array}{c}\text { Total Number of } \\
\text { IPOs }\end{array}$ & $\begin{array}{c}\text { Venture Backed } \\
\text { IPOs }\end{array}$ \\
\hline California & 1424 & 0.545 \\
Colorado & 159 & 0.289 \\
Connecticut & 149 & 0.308 \\
Florida & 298 & 0.208 \\
Georgia & 164 & 0.384 \\
Illinois & 218 & 0.247 \\
Massachusetts & 402 & 0.554 \\
Minnesota & 172 & 0.377 \\
New Jersey & 267 & 0.284 \\
New York & 122 & 0.171 \\
Ohio & 577 & 0.242 \\
Pennsylvania & 140 & 0.353 \\
Texas & & 0.285 \\
Washingin & & \\
\hline
\end{tabular}


Table 3: Descriptive Statistics, Venture Backed Firms versus Non-Venture Backed Firms for the Sample Period, 1975-2003

\begin{tabular}{|c|c|c|c|}
\hline Variable & $\begin{array}{c}\text { Venture Backed } \\
\text { (mean) }\end{array}$ & $\begin{array}{c}\text { Non-Venture } \\
\text { Backed (Mean) }\end{array}$ & $\begin{array}{c}\text { T-statistic for } \\
\text { difference }\end{array}$ \\
\hline Market Value (\$mil) & 1341.09 & 605.06 & 30.27 \\
\hline Assets (\$mil) & 406.33 & 1977.63 & 12.58 \\
\hline Sales (\$mil) & 372.01 & 634.59 & 10.52 \\
\hline Market-to-Book & 5.59 & 3.83 & 2.88 \\
\hline Leverage & 0.164 & 0.256 & 28.60 \\
\hline $\begin{array}{l}\text { Earnings as \% } \\
\text { market value }\end{array}$ & 0.006 & 0.011 & 24.76 \\
\hline $\begin{array}{l}\Delta \text { Earnings as } \% \\
\text { market value }\end{array}$ & 0.002 & 0.004 & 18.56 \\
\hline$\%$ Earnings $<0$ & 0.505 & 0.272 & 24.04 \\
\hline
\end{tabular}

Variable Definitions: Assets $=$ firm i's total assets at the end of year t. Market-to-book ratio $=$ the ratio of firm i's market value of equity to their book value of equity at the end of year. Leverage $=$ the ratio of firm i's long term debt to total book value of assets at the end of year t-1. Sales = firm i's sales revenues in year $\mathrm{t}$; Earnings as \% market value = firm i's earnings before extraordinary items in year $t$ scaled by its market value of equity at the end of year $\mathrm{t}-1 ; \Delta$ Earnings as $\%$ market value $=$ firm i's earnings in year $\mathrm{t}$ minus earnings in year $\mathrm{t}-1$, scaled by market value of equity at the end of year $\mathrm{t}-1$; 
Table 4: Tests of Earnings Informativeness of Venture Backed Firms versus NonVenture Backed Firms for the Sample Period 1975-2003

Annual returns-earnings regression

\begin{tabular}{|c|c|c|c|}
\hline & VC DUMMY & \multicolumn{2}{|c|}{ INSTRUMENTS } \\
\hline \multicolumn{2}{|l|}{ Variable } & STATE & YEAR \\
\hline \multirow[t]{2}{*}{ INTERCEPT } & 0.167 & 0.185 & 0.233 \\
\hline & $(46.83)$ & $(48.52)$ & $(55.76)$ \\
\hline \multirow[t]{2}{*}{ EARN } & 0.881 & 0.885 & 0.879 \\
\hline & $(18.21)$ & $(18.05)$ & (18.99) \\
\hline \multirow[t]{2}{*}{$\Delta \mathrm{EARN}$} & 0.551 & 0.423 & 0.354 \\
\hline & $(22.33)$ & & $(21.49)$ \\
\hline \multirow[t]{2}{*}{ VC*EARN } & -0.260 & -0.121 & -0.272 \\
\hline & $(-13.99)$ & $(-12.31)$ & $(-18.13)$ \\
\hline \multirow[t]{2}{*}{$\mathbf{V C} * \Delta \mathbf{E A R N}$} & -0.323 & -0.172 & -0.285 \\
\hline & $(-15.59)$ & $(-11.25)$ & $(-3.61)$ \\
\hline \multirow[t]{2}{*}{ EARN*LOSS } & -0.419 & -0.424 & -0.381 \\
\hline & $(-8.73)$ & $(-7.92)$ & $(-8.41)$ \\
\hline \multirow[t]{2}{*}{ EARN*HTECH } & -0.000 & -0.000 & -0.000 \\
\hline & $(-1.42)$ & $(-1.65)$ & $(-1.62)$ \\
\hline \multirow[t]{2}{*}{ EARN*SIZE } & 0.008 & 0.06 & 0.003 \\
\hline & $(18.07)$ & $(11.54)$ & $(8.91)$ \\
\hline \multirow[t]{2}{*}{ EARN*MB } & 0.001 & 0.001 & 0.002 \\
\hline & $(2.29)$ & $(4.41)$ & $(5.71)$ \\
\hline \multirow[t]{2}{*}{ EARN*LEV } & -0.01 & -0.01 & -0.02 \\
\hline & $(-3.83)$ & $(-2.97)$ & $(-1.86)$ \\
\hline Adj. $R^{2}$ & 0.0695 & 0.0741 & 0.095 \\
\hline
\end{tabular}




\section{Table 4 (Continued)}

Variables definitions: The dependent variable is $\mathrm{R}_{\mathrm{i}, \mathrm{t}}=$ firm i's 12-month cumulative raw return for fiscal year $\mathrm{t}$. The 12-month interval starts three months following the end of the fiscal year $\mathrm{t}-1$ and ends three months after the end of fiscal year $\mathrm{t}$. $\mathrm{EARN}_{\mathrm{i}, \mathrm{t}}=$ firm i's annual earnings (before extraordinary items) for fiscal year $t$, scaled by market value of equity at the end of fiscal year t-1. $\triangle E A R N_{i, t}=$ change in $E A R N_{i, t}$ between year $t-1$ and year $t$, scaled by market value of equity at the end of fiscal year $t-1$.

$\mathrm{VC}_{\mathrm{i}, \mathrm{t}}=$ venture capital backing dummy variable equal to 1 if the company is venture capital backed, zero otherwise. LOSS $_{\mathrm{i}, \mathrm{t}}=$ dummy variable equal to 1 if $\mathrm{EARN}_{\mathrm{i}, \mathrm{t}}<0$. $\mathrm{HTECH}_{\mathrm{i}, \mathrm{t}}=$ dummy variable equal to 1 if SIC code belongs to 2833-2836, 8731-8734, 7371-7379, 3570-3577,3600-3674. SIZE $\mathrm{E}_{\mathrm{i}, \mathrm{t}}=$ the log of firm's i market value in year $\mathrm{t}$. $\mathrm{MB}_{\mathrm{i}, \mathrm{t}}=$ Market-to-Book ratio, the ratio of firm i's market value of equity to their book value of equity at the end of year. $L V_{i, t}=$ firm's leverage, defined as the ratio of firm i's long term debt to total book value of assets at the end of year $\mathrm{t}-1$.

Instruments for venture capital backing are state of operation dummies and a dummy variable equal to 1 if the firm was founded after 1979 . Heteroskedasticity robust Tstatistics are shown in parentheses. 
Table 5: Market Reaction to Quarterly Earnings Announcements of Venture Backed Firms versus Non-Venture Backed Firms for the Sample Period 1975-2003

Panel A: Reaction to Earnings Announcements, Full Sample

\begin{tabular}{lccc} 
& VC DUMMY & \multicolumn{2}{c}{ INSTRUMENTS } \\
\hline Variable & & STATE & YEAR \\
\hline Intercept & 0.006 & 0.006 & 0.006 \\
& $(14.49)$ & $(14.48)$ & $(17.78)$ \\
UE & 0.201 & 0.204 & 0.212 \\
& $(32.69)$ & $(31.47)$ & $(32.21)$ \\
UE*VC & $\mathbf{- 0 . 0 6 8}$ & $\mathbf{- 0 . 0 7 8}$ & $\mathbf{- 0 . 0 3 0}$ \\
& $\mathbf{( - 6 . 9 4 )}$ & $\mathbf{( - 4 . 6 1 )}$ & $\mathbf{( - 3 . 2 1 )}$ \\
& & & \\
Adj. $R^{2}$ & $\mathbf{0 . 0 2 2}$ & $\mathbf{0 . 0 2 3}$ & $\mathbf{0 . 0 2 2}$ \\
\hline
\end{tabular}

Panel B: The Effect of Firm's Age on the Informativeness of Earnings, High-Tech Sample

\begin{tabular}{lccc} 
& VC DUMMY & \multicolumn{2}{c}{ INSTRUMENTS } \\
\hline Variable & & STATE & YEAR \\
\hline Intercept & 0.006 & 0.006 & 0.006 \\
& $(8.02)$ & $(7.44)$ & $(8.76)$ \\
UE & 0.252 & 0.249 & 0.257 \\
& $(32.69)$ & $(31.47)$ & $(32.21)$ \\
UE*VC & $\mathbf{- 0 . 2 2 2}$ & $\mathbf{- 0 . 1 8 1}$ & $\mathbf{- 0 . 1 3 2}$ \\
& $\mathbf{( - 3 . 4 2 )}$ & $\mathbf{( - 3 . 6 1 )}$ & $\mathbf{( - 2 . 9 9 )}$ \\
UE*AGE & $\mathbf{- 0 . 0 0 6}$ & -0.007 & -0.006 \\
& $\mathbf{( - 0 . 2 4 )}$ & $\mathbf{( - 0 . 8 7 )}$ & $\mathbf{( - 0 . 5 2 )}$ \\
UE*AGE*VC & $\mathbf{0 . 0 6 7}$ & $\mathbf{0 . 0 7 1}$ & $\mathbf{0 . 0 6 1}$ \\
& $\mathbf{( 1 . 9 6 )}$ & $\mathbf{( 1 . 9 2 )}$ & $\mathbf{( 2 . 0 1 )}$ \\
& & & \\
Adj. $R^{2}$ & $\mathbf{0 . 0 2 9}$ & $\mathbf{0 . 0 2 8}$ & $\mathbf{0 . 0 2 7}$ \\
\hline
\end{tabular}




\section{Table 5 (continued)}

Variables definitions: The dependent variable is cumulative abnormal return over the three days $(-1,1)$ centered on firm i's announcement of quarter q earnings for year $t$.

$U E_{i, t}=$ the unexpected earnings in firm i's quarter $\mathrm{q}$, year $\mathrm{t}$ earnings announcement, measured as reported earnings for quarter $\mathrm{q}$, year $\mathrm{t}$ minus reported earnings for quarter $\mathrm{q}$, year $t-1$, divided by market value of equity 30 days prior to the announcement. AGE is the $\log$ of number of years since the firm went public.

Instruments for venture capital backing are state of operation dummies and a dummy variable equal to 1 if the firm was founded after 1979. Heteroskedasticity robust Tstatistics are shown in parentheses. 
Table 6: The Effect of Venture Capital Ownership and Board of Directors Characteristics on Earnings Informativeness for Venture Backed Firms, 1978-1987

Panel A: Annual returns-earnings regressions VC DUMMY INSTRUMENTS

\begin{tabular}{|c|c|c|c|}
\hline Variable & & STATE & YEAR \\
\hline \multirow[t]{2}{*}{ Intercept } & 0.212 & 0.195 & 0.171 \\
\hline & $(8.75)$ & $(9.12)$ & $(8.27)$ \\
\hline \multirow[t]{2}{*}{ EARN } & 0.729 & 0.628 & 0.591 \\
\hline & $(5.26)$ & $(4.01)$ & $(4.17)$ \\
\hline \multirow[t]{2}{*}{$\Delta \mathrm{EARN}$} & 0.517 & 0.523 & 0.482 \\
\hline & $(9.81)$ & $(5.13)$ & $(5.12)$ \\
\hline \multirow[t]{2}{*}{ EARN*LOSS } & -0.385 & -0.342 & -0.324 \\
\hline & $(-5.45)$ & $(-4.98)$ & $(-4.24)$ \\
\hline \multirow[t]{2}{*}{ EARN*HTECH } & -0.145 & -0.187 & -0.147 \\
\hline & $(-2.14)$ & $(-2.55)$ & $(-2.78)$ \\
\hline \multirow[t]{2}{*}{ EARN*SIZE } & 0.005 & 0.004 & 0.004 \\
\hline & $(6.24)$ & $(5.87)$ & $(6.57)$ \\
\hline \multirow[t]{2}{*}{ EARN*MB } & 0.001 & 0.001 & 0.001 \\
\hline & (1.98) & $(1.87)$ & (1.94) \\
\hline \multirow[t]{2}{*}{ EARN*LEV } & -0.021 & -0.022 & -0.022 \\
\hline & $(-4.21)$ & $(-3.98)$ & $(-3.54)$ \\
\hline \multirow[t]{2}{*}{ EARN*OWN } & -0.302 & & -0.324 \\
\hline & $(-2.14)$ & & $(-1.66)$ \\
\hline \multirow[t]{2}{*}{$\Delta \mathbf{E A R N} * \mathbf{O W N}$} & -0.032 & & -0.034 \\
\hline & $(-1.92)$ & & $(-1.62)$ \\
\hline \multirow[t]{2}{*}{ EARN*SEAT } & & -0.072 & -0.068 \\
\hline & & $(-2.24)$ & $(-2.17)$ \\
\hline \multirow[t]{2}{*}{$\triangle \mathbf{E A R N}{ }^{* S E A T}$} & & -0.184 & -0.029 \\
\hline & & $(-1.98)$ & $(-1.82)$ \\
\hline Adj. $R^{2}$ & 0.0552 & 0.0554 & 0.0542 \\
\hline
\end{tabular}


Variables definitions: $E A R N_{i, t}=$ firm i's annual earnings (before extraordinary items) for fiscal year $\mathrm{t}$, scaled by market value of equity at the end of fiscal year $\mathrm{t}-1 . \Delta \mathrm{EARN}_{\mathrm{i}, \mathrm{t}}=$ change in EARN $_{\mathrm{i}, \mathrm{t}}$ between year $\mathrm{t}-1$ and year $\mathrm{t}$, scaled by market value of equity at the end of fiscal year $\mathrm{t}-1$.

$\mathrm{LOSS}_{\mathrm{i}, \mathrm{t}}=$ dummy variable equal to 1 if $\mathrm{EARN}_{\mathrm{i}, \mathrm{t}}<0$. $\mathrm{HTECH}_{\mathrm{i}, \mathrm{t}}=$ dummy variable equal to 1 if SIC code belongs to 2833-2836, 8731-8734, 7371-7379, 3570-3577,3600-3674. $\mathrm{SIZE}_{\mathrm{i}, \mathrm{t}}=$ the $\log$ of firm's i market value in year t. $\mathrm{MB}_{\mathrm{i}, \mathrm{t}}=$ Market-to-Book ratio, the ratio of firm i's market value of equity to their book value of equity at the end of year. $\mathrm{LEV}_{\mathrm{i}, t}=$ firm's leverage, defined as the ratio of firm i's long term debt to total book value of assets at the end of year $\mathrm{t}-1$.

$\mathrm{OWN}=$ percentage of equity owned by venture capital firms at date of IPO. SEAT $=$ percentage of seats on board of directors occupied by venture capital firms. Heteroskedasticity robust T-statistics are shown in parentheses. 
Table 6 (continued)

Panel B: Market Reaction to Earnings Announcements Conditional on Board and Venture Capital Ownership

\begin{tabular}{lccc}
\hline Variable & & & \\
\hline Intercept & 0.003 & 0.003 & 0.002 \\
& $(1.08)$ & $(0.98)$ & $(0.98)$ \\
UE & 0.098 & 0.104 & 0.105 \\
& $(7.22)$ & $(7.79)$ & $(7.51)$ \\
UE*OWN & $\mathbf{- 0 . 0 0 6}$ & & $\mathbf{- 0 . 0 0 1}$ \\
UE*SEAT & $\mathbf{( - 2 . 2 7 )}$ & $\mathbf{- 0 . 0 9 6}$ & $\mathbf{( - 0 . 1 7 )}$ \\
& & $\mathbf{- 0 . 0 9 2}$ \\
& & & $\mathbf{( - 2 . 4 5 )}$ \\
Adj. $R^{2}$ & $\mathbf{0 . 0 2 1}$ & $\mathbf{0 . 0 2 0}$ & $\mathbf{0 . 0 2 1}$ \\
\hline
\end{tabular}

Variables definitions: The dependent variable is cumulative abnormal return over the three days $(-1,1)$ centered on firm i's announcement of quarter q earnings for year $t$.

$U E_{i, t}=$ the unexpected earnings in firm i's quarter $\mathrm{q}$, year $\mathrm{t}$ earnings announcement, measured as reported earnings for quarter $\mathrm{q}$, year $\mathrm{t}$ minus reported earnings for quarter $\mathrm{q}$, year $\mathrm{t}-1$, divided by market value of equity 30 days prior to the announcement. OWN $=$ percentage of equity owned by venture capital firms at date of IPO. SEAT $=$ percentage of seats on board of directors occupied by venture capital firms. Heteroskedasticity robust T-statistics are shown in parentheses. 
Table 7: Regression Analysis of Stock Returns on Current Earnings with Different Time Intervals, Venture Backed Firms and Non-Venture Backed Firms for the Sample Period 1975-2003

$$
R_{i t, t-\tau}=\theta_{0}+\theta_{1(\tau)} \frac{E_{i t}}{P_{i t-\tau}}+v_{i t-\tau}
$$

Panel A:

$$
\theta_{1(\tau=1)} \quad \theta_{1(\tau=2)} \frac{\theta_{1(\tau=2)}}{\theta_{1(\tau=1)}}
$$

\begin{tabular}{llll}
\hline Venture & 1.091 & 1.669 & 1.53
\end{tabular}

Backed Firms

$\begin{array}{llll}\text { Non-Venture } & 1.213 & 2.280 & 1.88\end{array}$

backed Firms

Panel B: Including Control variables

\begin{tabular}{lccc}
\hline & $\theta_{1(\tau=1)}$ & $\theta_{1(\tau=2)}$ & $\frac{\theta_{1(\tau=2)}}{\theta_{1(\tau=1)}}$ \\
\hline $\begin{array}{l}\text { Venture } \\
\text { Backed Firms }\end{array}$ & 1.086 & 1.574 & 1.45 \\
$\begin{array}{l}\text { Non-Venture } \\
\text { backed Firms }\end{array}$ & 1.172 & 2.133 & 1.82
\end{tabular}

$R_{i t, t-\tau}$ is the buy-and-hold return for firm $\mathrm{i}$ over the period $\mathrm{t}-\tau$ to $\mathrm{t}, E_{\text {it }}$ is income before extraordinary items for the accounting period ended at time t, $P_{i t-\tau}$ is the stock price at the end of period t- $\tau$. $\theta_{1(\tau)}$ is the capital market's response to reported earnings. Panel A reports the results of estimating equation (5) for venture backed firms and non-backed firms. Panel B reports the results after controlling for different factors affecting the earnings-returns relationship as LOSS, HTECH, SIZE, MB, and LEV. The ratio $\frac{\theta_{1(\tau=2)}}{\theta_{1(\tau=1)}}$ measures the sensitivity of stock prices to current earnings relative to future earnings where a higher ratio represents a lower sensitivity of stock returns to current earnings relative to future earnings. 